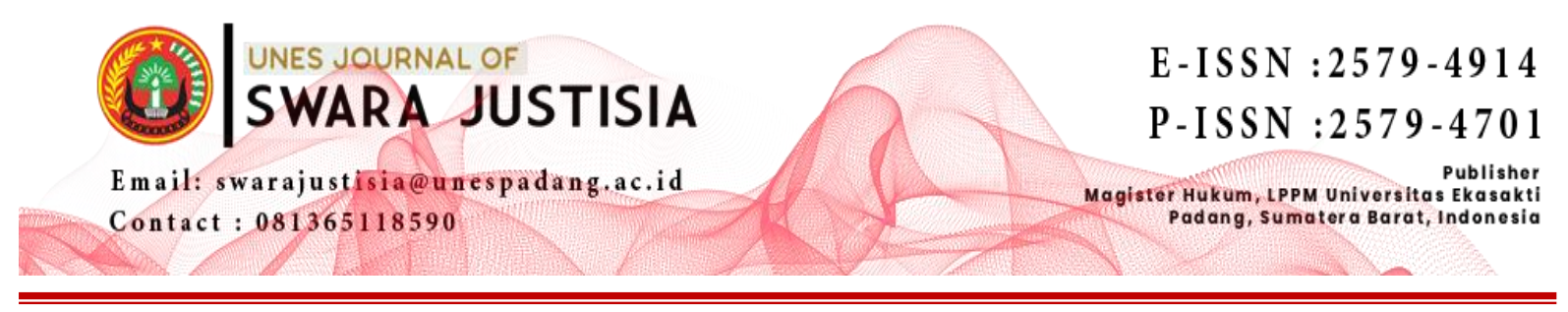

\title{
PERTANGGUNGJAWABAN PIDANA TERHADAP PELAKU TINDAK PIDANA PERNIAGAAN BAHAN BAKAR JENIS PREMIUM TANPA IZIN
}

\author{
Riko Tarianto \\ Program Magister Ilmu Hukum,Universitas Ekasakti, Padang \\ Email: rikotarianto@gmail.com
}

\begin{abstract}
The judge's consideration in making a decision against the perpetrators of the crime of trading premium fuel without a permit in Decision Number: 48/Pid.Sus/2019/PN.Pmn and Decision Number: 54/Pid.Sus/2020/PN.Pmn is based on juridical considerations, namely on the evidence presented in the trial examination. It has been fulfilled, namely the existence of statements from witnesses, statements of oil and gas experts who have expertise in the field of downstream oil and gas regulation as well as other evidence. In addition to juridical considerations, the judge also considers the sociological aspect of the defendant's actions in his decision. Second, the criminal liability of the perpetrators of the crime of trading premium fuel without a permit in Decision Number 48/Pid.Sus/2019/PN.Pmn and Decision Number: 54/Pid.Sus/2020/PN.Pmn is that the panel of judges handed down a decision in violation of Article 53 (d) of Law no. 22 of 2011 concerning Oil and Gas with a sentence of 6 months in prison, the imposition of this sentence as a form of criminal responsibility is felt to be far below the maximum criminal threat.
\end{abstract}

Keywords: Judge's Consideration, Accountability, Crime, Unlicensed Fuel Trading

\begin{abstract}
ABSTRAK
Pertimbangan hakim dalam menjatuhkan putusan terhadap pelaku tindak pidana perniagaan bahan bakar jenis premium tanpa izin pada Putusan Nomor: 48/Pid.Sus/2019/PN.Pmn dan Putusan Nomor: 54/Pid.Sus/2020/PN.Pmn adalah berdasarkan pertimbangan yuridis, yaitu pada alat bukti yang dikemukakan dalam pemeriksaan persidangan. Telah terpenuhi yaitu adanya keterangan dari saksi-saksi, keterangan ahli Migas yang mempunyai keahlian dibidang pengaturan hilir minyak dan gas bumi serta alat bukti lainnya. Selain pertimbangan yuridis, hakim juga mempertimbangkan aspek sosiologis dari perbuatan terdakwa pada putusannya. Kedua, Pertanggungjawaban Pidana Pelaku Tindak Pidana Perniagaan Bahan Bakar Jenis Premium Tanpa Izin Pada Putusan Nomor 48/Pid.Sus/2019/PN.Pmn dan Putusan Nomor : 54/Pid.Sus/2020/PN.Pmn adalah Majelis hakim menjatuhkan putusan dengan melanggar Pasal 53 (d) UU No. 22 Tahun 2011 tentang Minyak dan Gas Bumi dengan hukuman 6 bulan penjara penggenaan hukuman tersebut sebagai bentuk pertanggung jawaban pidana dirasakan masih jauh dibawah dari ancaman pidana maksimal.
\end{abstract}

Kata Kunci: Pertimbangan Hakim, Pertanggung jawaban, Pidana, Perniagaan Bahan Bakar Tanpa Izin 


\section{PENDAHULUAN}

Negeri Republik Indonesia merupakan negeri kepulauan yang banyak hendak materi galian. Materi galian ini, mencakup kencana, perak, tembaga, minyak serta gas alam, batu kobaran, serta lain-lain. Salah satu hasil alam Negeri Indonesia yang sudah bawa perkembangan cepat untuk keselamatan orang Indonesia merupakan minyak serta gas alam yang membagikan donasi lumayan besar kepada pendapatan Negeri. Tidak hanya berkontribusi dalam pendapatan Negeri, minyak serta gas alam ialah komuditas vital yang menggenggam andil berarti dalam penyediaan materi dasar pabrik, pelampiasan keinginan berarti hingga pengelolaannya butuh dicoba seoptimal bisa jadi supaya bisa digunakan buat kelimpahan serta keselamatan orang Indonesia. ${ }^{1}$ Perihal ini searah dengan apa yang di tegaskan dalam Artikel 33 bagian (2) serta bagian (3) Hukum Dasar Republik Indonesia Tahun 1945. Artikel 33 bagian (2).

Pengangkutan selaku cara terdiri atas serangkaian aksi mulai dari pencantuman ke dalam pengangkut, setelah itu dibawa oleh pengangkut mengarah ke tempat tujuan yang sudah didetetapkan, serta pembongkaran ataupun penyusutan ditempat tujuan. Mencegah penyalahgunaan dalam pengangkutan serta atau ataupun niaga materi bakar minyak yang sepatutnya menjajaki metode ataupun peraturan permisi pengangkutan pastinya diiringi dengan ganjaran kejahatan untuk tiap orang yang melanggarnya. ${ }^{2}$

Minyak serta gas alam ialah pangkal energi alam yang dipahami oleh negeri memiliki peranaan berarti dalam perekonomian nasional alhasil pengolaanya butuh dicoba seoptimal bisa jadi. Dalam usaha menghasilkan aktivitas upaya minyak serta gas alam untuk buat menciptakan kenaikan kelimpahan serta keselamatan orang sudah diresmikan Hukum No 22 Tahun 2001 mengenai Minyak serta Gas Alam. Hukum itu membagikan alas hukum untuk pembaruan serta penyusunan kembali aktivitas upaya migas.

Minyak serta gas alam senantiasa jadi kasus garis besar sebab keterbatasan jumlahnya serta karakternya. Materi bakar minyak (BBM) ialah salah satu produk penting dari hasil desalinasi minyak alam. Terdapatnya dominasi yang dicoba memunculkan sebagian penyimpangan, antara lain merupakan penyalahgunaan pengangkutan niaga materi bakar minyak yang disubsidi oleh Penguasa. Hukum No 22 Tahun 2001 mengenai Minyak serta Gas Alam sudah diundangkan pada bertepatan pada 23 November 2001 ialah pilar asal usul dalam membagikan alas hukum untuk langkah-langkah inovasi serta penyusunan kembali aktivitas upaya Minyak serta Gas Alam yang terdiri dari aktivitas upaya ambang serta aktivitas upaya asal. Aktivitas upaya ambang itu diatur pada Artikel 23 UU Migas.

Perbuatan kejahatan penyalahgunaan pengangkutan serta niaga materi bakar minyak bersubsidi, diatur dalam determinasi Artikel 53 hingga dengan Artikel 55 Hukum No 22 Tahun 2001 mengenai Minyak serta Gas Alam, aksi pengangkutan, pembagian, penampungan, akumulasi sampai pemasaran Materi Bakar Minyak (BBM).

Sedemikian itu banyaknya permasalahan yang mencuat di aspek pertambangan spesialnya dalam aspek minyak serta gas alam hal ekplorasi serta pemanfaatan tanpa memiliki kontrak kegiatan serta permisi upaya pengurusan minyak serta gas alam merupakan

1 Alikodra, Konservasi Sumber Daya Alam dan Lingkungan, Gadjah Mada University Press, Yogyakarta, 2012

${ }^{2}$ Abdulkadir Muhammad, Hukum Pengangkutan Niaga, Citra Aditya Bakti, Bandung. 1998, hlm 12 
kerangka balik terdapatnya Hukum No 22 Tahun 2001 mengenai Minyak serta Gas Alam. Hukum ini menata mengenai aktivitas upaya yang berhubungan dengan minyak serta gas alam, bagus aktivitas upaya asal ataupun aktivitas upaya ambang. Di Pariaman sedang kerap ditemukan kecurangan berbentuk akumulasi serta pemasaran materi bakar minyak (BBM) bersubsidi tipe solar serta gasolin bermutu. Hingga butuh dikenal gimana pertanggungjawaban kejahatan kepada pelakon perbuatan kejahatan penyalahgunaan pengangkutan niaga materi bakar minyak yang disubsidi oleh Penguasa alhasil bisa membagikan dampak kapok pada pelaku.

Di wilayah Hukum Pengadilan Negeri Pariaman telah terjadi beberapa kali tindak pidana Niaga bahan bakar minyak (BBM) tanpa izin seperti pada Putusan Nomor : 48/Pid.Sus/2019/PN/Pmn yaitu tersangka RIKI ARWIN Pgl RIKI dengan menggunakan mobil toyota avanza BA 1466 TA yang di dalam mobilnya terdapat tangki cadangan (modifikasi) yang berisi BBM jenis premium pada hari Selasa tanggal 23 Oktober 2018 sekira pukul 17.00 Wib di SPBU Kampung Pondok Pariaman Kec. Pariaman Tengah Kota Pariaman telah diamankan oleh Satuan Reserse Kriminal Polres Pariaman pada waktu mengisi BBM jenis premium yang sudah mencapai pengisian sebanyak Rp. 600.000,-(enam ratus ribu rupiah).

Selanjutnya Putusan Nomor : 54/Pid.Sus/2020/PN/Pmn dimana terdakwa melakukan Niaga bahan bakar minyak (BBM) tanpa izin dengan menggunakan mobil mobil merk Suzuki Carry ST 100 warna hijau tahun 1987 BA 1924 FI, yang mana didalam mobil tersebut sudah sudah ada tangki minyak cadangan (modifikasi) yang di las berbentuk petak dengan lubang pengisian seolah-olah lobang tangki BBM pemakaian kendaraan biasa yang bisa memuat BBM jenis bensin/premium dalam jumlah banyak dan di dalam tangki tersebut berisi BBM jenis premium/bensin yang banyak. Kedua putusan pengadilan ini merupakan keputusan pengadilan terhadap tindak pidana khusus dengan aturan umum yang juga bersifat khusus. Putusan yang diberikan Hakim terlalu ringan dibanding dengan yang terdapat pada peraturan perundang undangan yang dilanggarnya yaitu 6 (enam) bulan penjara dengan masa percobaan selama 1 (satu) tahun.

Permasalahan yang akan dibahas adalah Pertimbangan Hakim dalam menjatuhkan putusan serta pertanggungjawaban pidananya.

\section{METODE PENELITIAN}

Spesifikasi penelitian adalah deskriptif analitis, dengan metode pendekatan yuridis normative. Jenis data yang digunakan adalah data sekunder. Data sekunder diperoleh dari studi dokumen. Data yang diperoleh kemudian dianalisa secara kualitatif.

\section{PEMBAHASAN}

A. Pertimbangan Hakim Dalam Menjatuhkan Putusan Terhadap Pelaku Tindak Pidana Perniagaan Bahan Bakar Jenis Premium Tanpa Izin Pada Putusan Nomor 48/Pid.Sus/2019/PN.Pmn dan Putusan Nomor 54/Pid.Sus/2020/PN.Pmn

Pengambilan keputusan sangat diperlukan oleh Hakim dalam menentukan putusan yang akan dijatuhkan kepada terdakwa. Dikarenakan putusan yang akan dijatuhkan kepada terdakwa haruslah didasari dengan rasa tanggung jawab, keadilan, kebijaksanaan dan profesionalisme dari seorang Hakim. Hakim dalam memberikan putusan tidak hanya 
berdasarkan pada nilai-nilai hukum tetapi Hakim juga wajib menggali, mengikuti, dan memahami nilai-nilai yang hidup dalam masyarakat. Hal tersebut dijelaskan dalam Pasal 5 ayat (1) Undang-Undang Nomor 48 Tahun 2009 tentang Kekuasaan Kehakiman bahwa, "Hakim wajib menggali, mengikuti, dan memahami nilai-nilai hukum yang hidup dalam masyarakat". Ada dua kategori untuk memberikan telaah pada pertimbangan Hakim dalam menjatuhkan putusan. Kategori pertama akan dilihat dari segi pertimbangan yang bersifat yuridis dan yang kedua adalah pertimbangan yang bersifat non-yuridis. ${ }^{3}$

Pertimbangan hakim secara yuridis harus didasarkan pada alat bukti yang dikemukakan dalam pemeriksaan persidangan. Berdasarkan alat bukti yang sah dihubungkan dengan alat bukti yang ada dalam Putusan Nomor 54/Pid.Sus/2020/PN Pmn dan Putusan Nomor 48/Pid.Sus/2020/PN Pmn telah terpenuhi yaitu adanya keterangan dari saksi-saksi, keterangan ahli Migas yang mempunyai keahlian dibidang pengaturan hilir minyak dan gas bumi serta alat bukti lainnya. Barang bukti pada Putusan Nomor 54/Pid.Sus/2020/PN Pmn adalah 1 (satu) unit mobil merk Suzuki carry ST 100 warna hijau BA 1924 FL atas nama Nofi Asmira beserta STNK dan kunci kontak di dalam mobil terpasang tangki cadangan.

Sedangkan pada Putusan Nomor 48/Pid.Sus/2020/PN Pmn, barang bukti adalah 14 (empat belas) buah derigen kosong kapasitas 35 liter, BBM jenis premium yang berjumlah lebih kurang 90 liter dan satu unit mobil Avanza warna putih BA 1466 TA serta 1(satu) unit pompa nozzle merk WGM milik SPBU Kampung Pondok.

Dengan melihat Putusan Nomor 48/Pid.Sus/2020/PN Pmn yang dijadikan pertimbangan yuridis oleh hakim adalah semua fakta yang terungkap dalam persidangan yang ternyata berkesesuaian dengan unsur unsur pasal yang dilanggar yaitu Pasal 53 huruf d Undang-Undang Nomor 22 Tahun 2001 tentang Minyak dan Gas Bumi. Adapun pertimbangan yuridis pada putusan ini adalah keterangan saksi saksi dan terdakwa yang menyatakan bahwa terdakwa telah melakukan perbuatan pembelian BBM jenis premium dengan cara datang ke SPBU Kampung Pondok membawa mobil Toyota Avanza nomor polisi BA 1466 TA warna putih, lalu Terdakwa membeli BBM jenis premium dengan harga Rp 6.450,00 (enam ribu empat ratus lima puluh rupiah) per liter, selain membayar sesuai dengan harga bensin yang dibeli, Terdakwa juga memberikan uang cucuak kepada petugas pengisian di SPBU sejumlah Rp 10.000,00 (sepuluh ribu rupiah) sampai dengan Rp 15.000,00 (lima belas ribu rupiah) setiap pembelian Rp 300.000,00 (tiga ratus ribu rupiah) dan ketika Terdakwa ditangkap, saat itu Terdakwa membeli BBM jenis premium sebanyak Rp 600.000,00 (enam ratus ribu rupiah) dengan jumlah lebih kurang 90 (sembilan puluh) liter.

Selanjutnya bahwa BBM jenis premium yang dibeli oleh Terdakwa tersebut rencananya akan dibawa ke Agam dan akan dijual dengan harga Rp 7.700,00 (tujuh ribu tujuh ratus rupiah) per liter di daerah Bawan Agam sehingga Terdakwa memperoleh keuntungan sebesar Rp 225.000,00 (dua ratus dua puluh lima ribu rupiah) per derigen.

Perbuatan Terdakwa melakukan pembelian BBM jenis premium dan dimaksudkan untuk kembali menjual BBM jenis premium tersebut sehingga akan mendapatkan keuntungan dengan jumlah tertentu, dengan tidak mempunyai izin dari pejabat yang

\footnotetext{
${ }^{3}$ Muhammad Rusli, Hukum Acara Pidana Kontemporer, Citra Aditya Bakti, Bandung, 2007, hlm. 221
} 
berwenang sehingga perbuatan melakukan jual beli bahan bakar minyak jenis bensin tersebut tidak mempunyai izin dari pejabat yang berwenang melanggar Pasal 53 huruf d Undang-undang Nomor 22 Tahun 2001 Tentang Minyak dan Gas Bumi, sehingga Terdakwa haruslah dinyatakan telah terbukti secara sah dan meyakinkan melakukan tindak pidana.

Keterangan saksi adalah suatu alat bukti dalam perkara pidana yang berupa keterangan dari saksi mengenai suatu peristiwa pidana yang didengar, dilihat, dan dialami sendiri dengan menyebut alasan dari pengetahuannya itu. Keterangan seorang saksi baru mempunyai nilai pembuktian jika saksi tersebut disumpah terlebih dahulu sebelum memberikan keterangan. Dalam pembuktian kesalahan terdakwa dalam Putusan Nomor 48/Pid.Sus/2019/PN Pmn dihadirkan 6 (Enam) orang saksi yang telah diajukan oleh penuntut umum. Pada Putusan Nomor 54/Pid.Sus/2020/PN Pmn dihadirkan sebanyak 4 (empat) orang saksi.

Dalam menilai keterangan seorang saksi, hakim harus bersungguh-sungguh memperhatikan: ${ }^{4}$

1) Persesuaian antara keterangan saksi satu dengan yang lain;

2) Alasan yang mungkin dipergunakan oleh saksi untuk memberi keterangan tertentu;

3) Persesuaian antara keterangan saksi dengan alat bukti lain;

4) Cara hidup dan kesusilaan saksi serta segala Sesutu yang pada umumnya mempengaruhi dapat tidaknya keterangan itu dipercaya.

Hal yang juga menjadi sorotan penulis dalam perkara ini karena dalam pertimbangannya hakim menyebutkan;

Menimbang, bahwa oleh karena semua unsur dari Pasal 53 huruf d Undang Undang Nomor 22 Tahun 2001 tentang minyak dan gas bumi telah terpenuhi, maka terdakwa haruslah dinyatakan telah terbukti secara sah dan meyakinkan melakukan tindak pidana sebagaimana didakwakan dalam dakwaan alternatif pertama.

Penulis beranggapan "sikap" majelis hakim tanpa menjelaskan apa yang membuatnya langsung memilih Dakwaan Alternatif pertama tanpa memberikan "konsiderans" adalah hal yang menimbulkan pertanyaan. Meskipun berbentuk alternatif, dakwaan penuntut umum atas unsur tindak pidana melakukan niaga Bahan Bakar Minyak yang disubsidi Pemerintah tanpa izin, tetap layak untuk dipertimbangkan sebab dalam fakta persidangan Terdakwa menjual bahan bakar minyak itu kembali.

Selain pertimbangan yuridis diatas Hakim juga mempertimbangkan aspek sosiologis dari perbuatan terdakwa pada putusannya. Aspek sosiologis adalah aspek diluar dari aspek hukum yang juga harus dipertimbangkan Hakim. Aspek sosiologis dapat merupakan aspek memberatkan dan meringankan yang terdapat pada perbuatan dan pada diri terdakwa sendiri. Pada Putusan Nomor 48/Pid.Sus/2019/PN Pmn terdapat pertimbangan sosiologis yaitu adanya keadaan yang memberatkan yaitu perbuatan terdakwa menyebabkan kerugian negara dan perbuatan Terdakwa menyebabkan

\footnotetext{
${ }^{4}$ Hari Sasangka \& Lily Rosita, Hukum Pembuktian Dalam Perkara Pidana, Mandar Maju, Bandung, 2003, hlm 11
} 
kelangkaan bensin/premium. Keadaan meringankan terdakwa yang dipertimbangkan adalah sikap sopan terdakwa dipersidangan dan usia yang masih muda sehingga diharapkan dapat menyadari kesalahannya dan memperbaiki sikap dan tingkah lakunya.

Berbeda dengan pertimbangan yang terdapat pada putusan Nomor 54/Pid.Sus/2020/PN Pmn pertimbangan sosiologis yang diperhatikan Hakim adalah keadaan memberatkan dimana terdakwa dengan perbuatannya telah menimbulkan keresahan di tengah masyarakat dan tidak megindahkan UU Migas. Keadaan meringankan dari terdakwa adalah pengakuan dan penyesalan terdakwa terhadap perbuatannya. Berdasarkan pemeriksaan dipersidangan terungkap bahwa terdakwa melakukan tindak pidana aquo disebabkan karena gaji terdakwa setiap bulannya tidak mencukupi sebagai operator pompa di SPBU dan selain itu Terdakwa juga harus membiayai satu orang istri dan tiga anak yang masih kecil-kecil dimana anak pertama Terdakwa bersekolah di SMA, anak ke dua kelas 5 SD serta anak ke tiga mau masuk TK.

Pada saat terdakwa diadili adalah pada masa Pandemi Covid 19 sehingga selain faktor keluarga Terdakwa di atas, Lembaga Permasyarakatan Pariaman sudah sesak (full capacity) dan ingin mengurangi jumlah warga binaan (program asimilasi) dan kondisi ini diperparah dengan merebaknya wabah Pandemi Covid-19 di seluruh daerah di Indonesia termasuk Kota Pariaman, maka oleh karena itu Majelis sepakat untuk menjatuhkan putusan berupa pidana bersyarat (perbuatan) dan denda kepada Terdakwa.

\section{B. Pertanggungjawaban Pidana Pelaku Tindak Pidana Perniagaan Bahan Bakar Jenis Premium Tanpa Izin Pada Putusan Nomor 48/Pid.Sus/2019/PN.Pmn Dan Putusan Nomor 54/Pid.Sus/2020/PN.Pmn.}

Berbicara tentang pertanggungjawaban, maka tidak dapat dilepaskan dengan tindak pidana, walaupun dalam pengertian tindak pidana tidak termasuk masalah pertanggungjawaban pidana. Tindak pidana hanya menunjuk kepada dilarangnya suatu perbuatan. Dasar adanya tindak pidana adalah asas legalitas, sedangkan dasar dapat dipidananya pembuat adalah asas kesalahan, berarti bahwa pembuat tindak pidana hanya akan mempertanggungjawabkan suatu perbuatan pidana jika ia mempunyai kesalahan dalam melakukan tindak pidana tersebut.

UU No. 22 Tahun 2001 tentang minyak dan gas bumi tidak sedikitpun menyinggung apakah seseorang patut dimintai pertanggungjawaban atau tidak ketika seseorang tersebut membeli serta menggunakan Bahan Bakar Minyak yang dijual tanpa memiliki izin usaha. Sehingga jika seseorang yang membeli serta menggunakan Bahan Bakar Minyak Eceran yang dijual tanpa memiliki izin usaha tidaklah dapat dimintai pertanggung jawaban pidana. Hal tersebut sejalan dengan ketentuan dalam Pasal 1 ayat (1) KUHP yang menyatakan bahwa "Suatu perbuatan tidak dapat dipidana, kecuali berdasarkan kekuatan ketentuan perundang-undangan pidana yang telah ada", atau dalam Hukum Pidana sering dikenal dengan Asas Legalitas. Namun dalam perjalanannya ketika hal tersebut dibiarkan berlarut-larut tanpa adanya suatu hal yang membatasinya, setiap orang dapat dengan bebas menggunakan atau membeli Bahan Bakar Minyak yang dijual secara tidak sah karena mereka menyadari bahwa hal tersebut tidaklah dilarang dalam Undang-undang.

Kondisi inilah yang memicu terjadinya penyimpangan kegiatan usaha hilir di Kota 
Pariaman, diantaranya adalah pengangkutan, penyimpanan dan Niaga. Masyarakat diresahkan dengan aksi penimbunan BBM terutama BBM bersubsidi jenis premium, sehingga sering terjadi kelangkaan di beberapa SPBU. Fenomena ini menjadikan aparat kepolisian instens untuk berpatroli rutin, ketika dalam kegiatan operasi rutin tersebut, aparat mencurigai sebuah mobil yang tengah memuat BBM berlebihan dari kapasitas tangka dan ketika ditanya tidak mampu menunjukkan surat izin pengangkutan, oleh karena itu aparat meminta sopir beserta mobil yang sedang dikendarainya untuk menuju ke Polres Pariaman.

Dari kedua putusan pengadilan yang dijumpai, terlihat pidana yang dijatuhkan oleh hakim juga bervariasi baik hukuman penjara maupun denda yang diterapkan. Akan tetapi putusan tersebut tidak berpola meskipun jenis tindak pidananya adalah sama. Pada putusan Nomor 48/Pid.Sus/2019/PN Pmn dan Putusan Nomor 54/Pid.Sus/2020/PN Pmn Majelis hakim menjatuhkan putusan dengan Pasal 53 (d) UU No. 22 Tahun 2011 tentang Minyak dan Gas Bumi, yaitu perbuatan niaga tanpa izin usaha. Pada Pasal ini ancaman pidana maksimal adalah pidana penjara paling lama 3 (tiga) tahun dan denda paling tinggi Rp. 30.000.000.000,00 (tiga puluh miliar).

Pada putusan Nomor 48/Pid.Sus/2019/PN Pmn bertanggung jawaban pidana yang dijatuhkan Hakim adalah bersalah melakukan tindak pidana melakukan niaga bahan bakar minyak (BBM) tanpa dilengkapi izin usaha niaga dengan hukuman pidana penjara selama 4 (empat) bulan dan denda sejumlah Rp 3.000.000,00 (tiga juta rupiah) dengan ketentuan jika denda tersebut tidak dibayar diganti dengan pidana kurungan selama 1 (satu) bulan. Pada putusan Nomor 54/Pid.Sus/2020/PN Pmn dengan tindak pidana yang sama dijatuhi hukuman pidana penjara selama 6 (enam) bulan dan menyatakan pidana tersebut tidak perlu dijalankan oleh Terdakwa kecuali dikemudian hari dengan putusan Hakim diperintahkan lain karena sebelum habis masa percobaan selama 1 (satu) tahun Terdakwa telah melakukan perbuatan pidana. Pidana ini disebut dengan pidana percobaan atau pidana bersyarat. Selain itu juga Menghukum Terdakwa dengan pidana denda sejumlah Rp 5.000.000,- (lima juta rupiah) dengan ketentuan apabila denda tidak dibayar diganti dengan pidana kurungan selama 3 (tiga) bulan. Penggenaan hukuman tersebut sebagai bentuk pertanggung jawaban pidana dirasakan masih kurang dari ancaman pidana maksimal yang terdapat dalam Pasal 53 huruf d yang dilanggar yaitu pidana penjara paling lama 3 (tiga) tahun dan denda paling tinggi Rp. 30.000.000.000,00 (tiga puluh miliar).

Berdasarkan sejarah ada enam macam pengenaan berat dan ringannya denda yang dapat dijatuhkan kepada pelaku kejahatan. Pertama adalah dilihat dari strata pelaku, jika pelaku dari kelas atas, maka pidana denda dijatuhkan lebih berat dibandingkan dengan pelaku dari kelas sosial rendah. Kedua adalah dilihat dari korbannya, apakah korban berupa manusia atau binatang. Tetapi tidak dilihat dari jenis kelaminnya, sehingga keberadaan manusia lebih dipertimbangkan. Ketiga adalah dilihat dari jumlah korban yang terdampak, keadaan ini terkesan riskan jika berimplikasi pada korban secara luas dan massif. Keempat adalah pada saat perbuatan itu terlaksana, artinya dalam KUHP juga dikenal siang dan malam, dimana faktor malam hari menjadi pemberat dalam penjatuhan pidana. Kelima adalah adanya suatu niatan dari pelaku tindak pidana. Konsep ini ternyata diakomodir juga dalam KUHP, dimana adanya kesengajaan dan kealpaan. Keenam adalah 
dilihat dari objek perbuatan, obyek disini bukanlah manusia melainkan berupa barang atau binatang. Ada kemiripan antara nomor dua dengan enam terkait dengan obyek kejahatan, tetapi nomor enam lebih menekankan pada kerugian berupa barang dan atau binatang. Dari keenam konsep tersebut, ternyata sejarah lebih menekankan pada pelaku kejahatan, karena ini akan berlaku terhadap pembayaran sejumlah uang dari pelaku kepada korban. Terlebih, adanya penghambaan pelaku untuk mengabdikan dirinya kepada korban yang dirugikan atas perbuatannya, sehingga bentuknya lebih kepada perbudakan tetapi dilegalkan menurut hukum terutama yang berkuasa pada saat itu adalah raja selaku pemberi dan penentu keadilan.5

Putusan yang dijatuhkan oleh hakim ini merujuk pada Pasal 53 huruf d UU Migas dimana ketentuan undang-undang hanya mencantumkan pidana penjara maksimum dan denda maksimum. Mengingat obyek yang dijadikan sebagai tindak pidana adalah milik pribadi terdakwa dan pembeliannya secara legal, tetapi justru malah disita untuk Negara. Seharusnya ada pedoman khusus dalam penjatuhan pidana pengganti denda, dimana undang-undang selalu menyertakan pidana pengganti jika terdakwa tidak mampu membayar sejumlah uang. Jaksa selaku eksekutor pelaksana putusan hakim, harus melakukan upaya lelang harta benda terdakwa jika memang dalam persidangan terdakwa tidak sanggup untuk membayar sejumlah uang. Langkah ini dilakukan sebagai jaminan bahwa denda akan terbayarkan. Namun apabila hasil lelang harta benda terdakwa masih belum mencukupi atau setara dengan denda yang dijatuhkan, baru dituangkan pidana pengganti denda dalam putusan selama tidak melebihi pidana pokoknya. Mekanisme pemidanaan demikian dapat dijadikan rujukan dalam pelaksanaan pidana denda.

Pada kedua putusan diatas pidana yang dijatuhkan sangat jauh dibawah pidana maksimal yang diatur oleh undang undang. Hal ini disebabkan karena pertimbangan nilai kerugiaan yang tidak besar dan perniagaan minyak premium yang dilakukan masih dalam taraf usaha perorangan yang sifatnya kecil kecilan. Bahkan pada putusan Nomor 54/Pid.Sus/2020/PN Pmn dijatuhakan pidana percobaan dengan pertimbangan kapasitas lembaga pemasyarakatan yang penuh dan kondisi masa pandemic covid 19 namun terhadap terdakwa dijatuhi pidana denda yang tinggi yaitu sebesar 5 (lima) juta rupiah.

\section{PENUTUP}

Hakim dalam penjatuhan hukum terhadap perbuatan perniagaan bahan bakar minyak bersubsidi tanpa izin dapat memberikan hukuman yang mendekati maksimal dengan mempertimbangan jumlah kerugian yang timbul akibat perbuatan tersebut. Apabila jumlah kerugian yang timbul tidak begitu besar seperti kasus diatas dapat dialihkan dengan penyelesaian di luar sistem peradilan pidana karena tidak seimbang antara biaya peradilan perbuatan tersebut dengan nilai kerugian yang ditimbulkannya.

\section{DAFTAR PUSTAKA}

Alikodra, Konservasi Sumber Daya Alam dan Lingkungan, Gadjah Mada University Press, Yogyakarta, 2012

\footnotetext{
${ }^{5}$ Andi Hamzah, Sistem Pidana dan Pemidanaan Indonesia, PT. Pradnya Paramita, Jakarta, 1993, hlm.
} 14 
Abdulkadir Muhammad, Hukum Pengangkutan Niaga, Citra Aditya Bakti, Bandung. 1998 Muhammad Rusli, Hukum Acara Pidana Kontemporer, Citra Aditya Bakti, Bandung, 2007 Hari Sasangka \& Lily Rosita, Hukum Pembuktian Dalam Perkara Pidana, Mandar Maju, Bandung, 2003

Andi Hamzah, Sistem Pidana dan Pemidanaan Indonesia, PT. Pradnya Paramita, Jakarta, 1993 